DOI: https://doi.org/10.34069/AI/2022.49.01.11 How to Cite:

Lushchyk, Y., Pikulytska, L., \& Tsyhanok, H. (2022). The impact of project work on international students' foreign (Ukrainian) language acquisition in high education. Amazonia Investiga, 11(49), 93-107. https://doi.org/10.34069/AI/2022.49.01.11

\title{
The impact of project work on international students' foreign (Ukrainian) language acquisition in high education
}

\section{Вплив проектної діяльності на вивчення іноземними студентами іноземної (української) мови в системі вищої освіти}

Received: November 11, 2021

Accepted: January 3, 2022
Written by:

Yuliia Lushchyk ${ }^{40}$

https://orcid.org/0000-0003-4306-1949

Liudmyla Pikulytska ${ }^{41}$

https://orcid.org/0000-0001-5780-4454

Hanna Tsyhanok ${ }^{42}$

https://orcid.org/0000-0002-6303-6831

\section{Антотація}

Стаття присвячена проектній роботі під час вивчення іноземної мови іноземними студентами у ЗВО. Існує припущення, що проектна робота може позитивно впливати на оволодіння іноземними студентами українською мовою як іноземною. Стаття має на меті охарактеризувати проектну діяльність та довести, чи може вона покращити опанування студентами іноземною мовою. Для досягнення мети були використані теоретичні (аналіз, узагальнення) та емпіричні (спостереження, перевірка, експеримент) методи. Було проведено експеримент, у якому взяли участь 32 іноземних студента першого курсу. Експериментальна $(\mathrm{n}=16)$ і контрольна $(\mathrm{n}=16)$ групи пройшли попереднє та наступне тестування у вересні та грудні 2020 року відповідно. У студентів перевірялися навички читання, письма, аудіювання, говоріння та користування мовою. Дані, отримані до експерименту, продемонстрували майже однаковий рівень володіння мовою в обох групах. Результати експерименту показали, що учасники експериментальної групи вдосконалили усі аспекти володіння іноземною мовою. Ключовими моментами, які позитивно вплинули на досягнення студентів, були соціально-культурна тематика проектів, яка відповідає їхнім інтересам, спеціально розроблена програма для підготовки проекту та підтримка викладачів. Ці результати підтвердили

\footnotetext{
${ }^{40}$ Associate Professor, Department of Foreign Languages, Sumy National Agrarian University, Sumy, Ukraine

${ }^{41}$ Senior Lecturer, Department of Foreign Languages, Sumy National Agrarian University, Sumy, Ukraine.

${ }^{42}$ Senior Lecturer, Department of Foreign Languages, Sumy National Agrarian University, Sumy, Ukraine.
} 
Keywords: foreign language, higher education institution (HEI), international students, project work, social-cultural topics.

\section{Introduction}

Rapid integration processes in various spheres of politics, economics, culture, ideology, mixing and displacement of nations and languages, internationalization of higher education actualize the problem of intercultural communication, mutual understanding of communication participants belonging to different cultures. Universities in many countries are becoming active providers of educational services not only for citizens of their country but also for foreigners. For example, the number of international students who get higher education at Ukrainian universities, both in English and Ukrainian, is growing every year. These processes require changes in teaching methodology and solving new problems in the theory and practice of teaching foreign languages.

Long experience of authors' teaching proves that students face similar difficulties in foreign language learning such as fear of making mistakes in pronunciation or grammar; shortage of vocabulary to express their opinions or feelings in a foreign language and so on. In our opinion, teaching foreign languages should be based on an activity approach, which means that the learning process should be as close as possible to the learner's future activity in society. We share the opinion that the activity approach is based on the recognition of activity as the basis, means and decisive condition for the development of creative and active personality. It this particular approach that makes it possible to avoid the gap between theoretical knowledge and its use in practice (Biletska et al., 2021).

Working with information in any language requires the development of certain intellectual skills: the ability to analyze information, select the necessary facts, build them in a logical sequence, the ability to put forward arguments and counterarguments, etc.

So, we think that it is a matter of great importance to find out an alternative way to provide students with appropriate and creative activities for effective foreign language learning meeting their interests and needs. That's why we believe that доцільність включення проектної роботи до викладання курсів іноземної мови для іноземних студентів.

Ключові слова: іноземна мова, заклад вищої освіти (ЗВО), іноземні студенти, проектна робота, соціально-культурна тематика.

the process of foreign language learning can be effectively actualized by using the method of project work, which combines the ability to work with various information sources and the ability to adequately present the work result. Project activity is a direction of pedagogy, which is aimed at the applied use and improvement of students' knowledge and skills in modern educational systems (Yermakov, 2003). Based on the points mentioned above, the project approach seems to be one of the few available, effective and productive ways to develop, or at least sustain international learners' knowledge of the foreign language.

The discussions of aspects regarding projectbased learning are interesting and various. However, the impact of the project activity on international students' foreign (Ukrainian) language acquisition in higher education has not been a matter of thorough consideration. This determines the relevance of the theme of our research. The study is timely and can contribute to the scientific purposes of theory and methods of teaching foreign languages on the whole and international students in particular. It results can be used to achieve some practical benefits to stimulate foreign language learning by means of project work.

The study hypothesizes that the project work in the context of the international students' foreign (Ukrainian) language learning can support, or even improve their language skills. The compliance of project tasks and topics with the international students' needs and interests is believed to be essential for effective project work implementation.

The purpose of this article is to characterize the peculiarities of the project activity and prove whether it can improve international students' foreign (Ukrainian) language acquisition in higher education. Thus, the paper objectives are: to analyze the theoretical grounds (definition, gist, characteristics, principles, typology) of international students' project activities in the context of foreign (Ukrainian) language learning and teaching; to take a fresh look at the project 


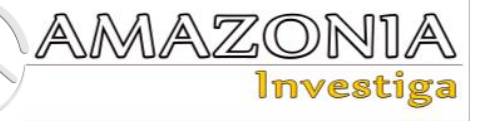

activity implementation and find out its impact on international students' foreign (Ukrainian) language proficiency by the experimental way.

\section{Theoretical Framework}

There is no single opinion in education science on how to define the project method. The following ideas are worth mentioning. The project method is a teaching and learning technique in which the learners undertake a task, or a research exercise, that has usually been initiated by the teacher (Jarvis \& Wilson, 2005). The project method is also discussed under headings like project work, project approach, and project-based learning (Peters, 2017). "It is a subform of action-centred and student-directed learning in which learners engage in practical problem solving for a certain period of time" (Peters, 2017).

The modern method of teaching foreign languages has its specific transformations of the definition of the project work. In particular, the project work is considered as a certain set of learners' training and cognitive techniques and actions that allow solving a particular problem as a result of individual cognitive actions and involving the presentation of these results in the form of a specific product of activity (Polat, 1989). According to Khatamova, Ismailova \& Akbarova (2019), the project is a creative activity of learners, corresponding to their physiological and intellectual abilities, taking into account the requirements of the standards. The main idea of such an approach to teaching a foreign language is to shift the emphasis from various types of exercises to the active mental activity of students, which requires proficiency in certain linguistic means for its design (Khatamova, Ismailova \& Akbarova, 2019). Gasparyan, Lashova \& Pipchenko (2018) consider the project work as a special form of organizing the students' communicative and cognitive activity, having a common goal, agreed ways to achieve an overall result. Haines's explanation of project work should not be left out: "Projects are multi-skill activities focusing on topics or themes rather than

Table 1.

Didactic typology of projects (Konysheva, 2004, 72). on specific language targets. In addition to project work provides students with opportunities to recycle known language and skills in a relatively natural context" (Haines, 1989).

Also, scholars highlight the characteristic features of the project work: use of acquired knowledge and skills; compliance of topics and tasks meet the students' real interests and needs; creative orientation of the process; focus on practical results and very often a visual presentation of the result; emphasis on students' work (individual and group) and intensive outof-class activity; the use of the language in situations close to the conditions of real communication; selection of language material, types of tasks and work sequence in accordance with the theme and purpose of the project (Koval, 2019).

In the context of project-based learning, the matter of appropriate organization of the project work is of great importance. Such activities as preparation, planning the way to perform the project, performance of it, and reporting the products and assessing are key steps that allow the creation of more opportunities for the learners to study (Cuong, 2017).

There are furthermore different approaches to the typology of projects in the language teaching environment. For instance, three types of projects are distinguished: a group project, in which research is carried out by the whole group, and each student studies a certain aspect of the chosen topic; mini-project, dealing with conducting an individual sociological survey using questionnaires and interviews; a project based on work with literature, implying selective reading on the topic of interest to the student and suitable for individual work (Shcherbakova, 2011).

Also, Konysheva's idea to present the didactic typology of project works developed by Polat in the form of a table merits attention.

\begin{tabular}{ll}
\hline The distinctive criterion of project type & Sub-types \\
\hline By activity & Research, creative, role-playing, informational, \\
By substantive areas & practice-oriented \\
By nature of coordination & Monoprojects, interdisciplinary projects \\
By nature of the contacts & Project with open, explicit, hidden coordination \\
By number of participants & Domestic, regional, international \\
For the duration of holding & Individual, paired, group \\
\hline
\end{tabular}


In the learning process of HEI, the abovementioned types of project works do not exist in their pure form, so educationalists have to deal with mixed types of project works. However, any project work has one or another type of coordination, terms, and stages of implementation, higher or lower number of participants. It should be noted that project works should be applied and intercultural. That is, the content and methods of their implementation should correspond to the needs and main types of activities of students.

\section{Methodology}

Following the purpose and objectives of the research theoretical and empirical methods were used. The theoretical ones were analysis and generalization of scientific literature on the problem of the research. The empirical methods included observation, testing and experiment to find out if project activity improves the international students' foreign (Ukrainian) language acquisition and statistical methods to evaluate the results of the experiment.

The experiment was carried out in Sumy National Agrarian University (SNAU), Ukraine, in autumn-winter 2020 with first-year international students. Students gave written consent to participate in the experiment. They were informed about the possibility to refuse without negative consequences. The experimental group consisted of 16 international students (age 18-21) who were involved in social-cultural foreign (Ukrainian) language project activity in addition to learning and teaching under traditional methods. The control group included 16 international students (age 1821) as well but they were taught traditional methods. The gender differences were not taken into consideration in the research. The same tasks and activities were used for the analysis of the language acquisition level (writing, reading, listening, speaking, and use of language skills) before (September 2020) and after (December 2020) the experiment.

To compare the test result between pre-test and post-test in both groups the authors use some steps. Those are calculating the students' mean score of the test, calculating the group's mean score percentage, and calculating the students' improvement score from pre-test to post-test into percentage in each group. In analyzing the data of the pre-test, the first step is to get the mean score of the control and experimental group. It is calculated as follows: $\overline{\mathrm{X}}=\frac{\Sigma \mathrm{x}}{n}$. Where, $\overline{\mathrm{X}}-$ mean score, $\sum \mathrm{x}$ - the sum of the observations, $\mathrm{n}-$ number of the observations. The second step is to know the percentage of students' mean score. It is calculated by using as follows: $\mathrm{P}=\frac{\bar{X}}{N} x 100 \%$. Where, $\mathrm{P}$ - the percentage of students' mean score, $\overline{\mathrm{X}}$ - mean score, $\mathrm{N}$ - maximum mark for the test (equal to 100 points). To find the improvement score from pretest to post-test the following formula is used: $P_{i}=P_{2}-P_{1}$. Here, $P_{i}$ - the percentage of improvement score, $P_{2}$ the percentage of students' mean score for posttest, $P_{1}-$ the percentage of students' mean score for the pre-test. The calculation results were rounded to integers following the rounding rules.

\section{Results}

After a thorough analysis of modern scholars' opinions on project activities mentioned above, we consider the project work in the context of international students' foreign (Ukrainian) language learning as the organization of international students' communicative and cognitive activities in a manner that involves them in active learning and reciprocal interaction in the education environment. The purpose of such interaction is a creative search for the necessary material and its further processing to solve an actual problem. Such a communicative and cognitive activity ends with the presentation and defense of a very real practical result, designed in one way or another.

The implementation of the foreign language project for international students should underpin the following basic principles of using projectbased methods: the principle of communication; the principle of situational conditionality; the principle of problematicity; the principle of costudy of language and culture; the principle of autonomy. In addition, the topics for the project activity should be elaborated taking into account the preferable communicative area and the syllabus requirements. Regarding the first-year international students, their preferable communicative area is social-cultural which is in line with the foreign language course of the HE (Lushchyk et al., 2020).

By the didactic typology of project works presented above, to work with first-year students we proposed projects that can be characterized by the type of activity as search information; subject matter area as socio-cultural; open coordination project; by the number of participants - group project, by the length - average length (2 months). Introducing the project work into the training practice the set of goals are suggested to be achieved: provide a group of students an 


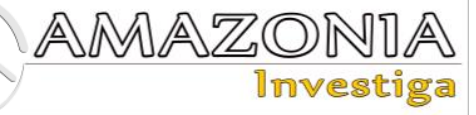

opportunity to use the acquired research experience; to implement students' interest in the topic of research, enhance the knowledge about it; to demonstrate, sustain and improve the level of proficiency in a foreign language; to achieve a higher level in learning, self-development, social maturity. Students were asked to prepare a sociocultural project in the form of a PowerPoint presentation on the following topics: "Guide to the country of studying for foreigners"; "Guide to the city of studying for foreigners"; "The city of studying for international students' attraction"; "Places that impressed me in the

Table 2.

Stages and steps of project work. country (city) of studying"; "National customs and traditions".

In the process of implementing the project method as training research students carry out various activities. They can be represented in the form of a chain: problem statement, collection of available data, "verification" of data, experimentation, drawing up a research plan, formulating conclusions, the reflection of the results. In general, the project work is carried out in several stages. They are detailed in table 2 .

\begin{tabular}{ll}
\hline Stages & Steps \\
\hline & 1. Defining the topic of the project. \\
2. Defining the purpose of the project. & 3. Discussion of the project structure, drawing up a work plan. \\
4. Presentation of language material and pre-communicative training. & 5. Collection of information from various sources (student's life experience, \\
& work with information on the topic). \\
& 1. Group work. \\
& 2. Adjustment work (discussion of interim results, teacher's facilitation to \\
& students and correction of possible students' mistakes, presentation and \\
& processing of new material: lexical, grammatical, socio-cultural). \\
3esign & eachalysis of the collected information, coordination of students' actions in \\
& 1. Preparation of the project presentation (PowerPoint, video for social \\
networks, photo exhibition). & 2. Demonstration of project results. \\
Technological & Project assessment and analysis: \\
& - carried out by the teacher (control of language acquisition and development of \\
& communicative competence); \\
- self-evaluation; & - mutual evaluation;
\end{tabular}

Next an example of the organization of one of the projects "National customs and traditions" is introduced. Students involved in the project had a language proficiency level of A2-B1. Preparation and work on the project lasted 30 hours over 12 weeks. The aim was to create a guidebook about customs, traditions and holidays in the country of studying. Students used their smartphones, cameras, video cameras, computers as the equipment to carry out the projects. The teacher's preliminary preparation involved the creation of recommendations for students, visits to the library, museums, galleries, speaking local people. Preliminary training of students covered the creation of a list of holidays, customs, traditions that they would like to explore and highlight in their project, as well as the search for information about them in various sources.
Work on the project began with a discussion of research objects (family holidays and traditions, public holidays, folk customs, traditions, holidays), etc. Then international students were divided into groups of 2-3 people and after the discussion chose the objects of the project to their preference. The teacher acted as a moderator and facilitator of their work in accordance with the stages and steps described above. Students began to gather information for their projects, which was coordinated and adjusted by the teacher. If necessary, the teacher assisted in analyzing the collected information, in preparing the project results for demonstration. The projects were presented to groupmates, students of the preparatory department.

At the beginning of the experiment, a correction course of acquired knowledge for 5 weeks at the beginning of the academic year in the amount of 
10 hours was taught to students of both groups (control and experimental). The data obtained as pre-testing showed that students in both groups had almost a similar level of language proficiency. This is shown in Table 3, Table 4, Diagram 1.

Table 3.

Pre-testing results in the control group.

\begin{tabular}{rll}
\hline & Respondent's name & $\begin{array}{l}\text { students' pretest score } \\
(0-100)\end{array}$ \\
\hline 1. & Student 1 & 69 \\
2. & Student 2 & 75 \\
3. & Student 3 & 67 \\
4. & Student 4 & 78 \\
5. & Student 5 & 63 \\
6. & Student 6 & 90 \\
7. & Student 7 & 79 \\
8. & Student 8 & 86 \\
9. & Student 9 & 92 \\
10. & Student 10 & 71 \\
11. & Student 11 & 76 \\
12. & Student 12 & 60 \\
13. & Student 13 & 74 \\
14. & Student 14 & 93 \\
15. & Student 14 & 81 \\
16. & Student 16 & 84 \\
Total Score & & 1238 \\
Students' mean score & & 77.37 \\
Mean score in percentage & & $77.37 \%$ \\
\hline
\end{tabular}

Table 4.

Pre-testing results in the experimental group.

\begin{tabular}{rll}
\hline & Respondent's name & $\begin{array}{l}\text { students' pretest score } \\
(0-100)\end{array}$ \\
\hline 1. & Student 1 & 75 \\
2. & Student 2 & 75 \\
3. & Student 3 & 82 \\
4. & Student 4 & 67 \\
5. & Student 5 & 60 \\
6. & Student 6 & 80 \\
7. & Student 7 & 70 \\
8. & Student 8 & 90 \\
9. & Student 9 & 73 \\
10. & Student 10 & 83 \\
11. & Student 11 & 85 \\
12. & Student 12 & 73 \\
13. & Student 13 & 92 \\
14. & Student 14 & 65 \\
15. & Student 15 & 74 \\
16. & Student 16 & 87 \\
Total Score & & 1231 \\
Students' mean score & & 76.93 \\
Mean score in percentage & & $76.93 \%$ \\
\hline
\end{tabular}




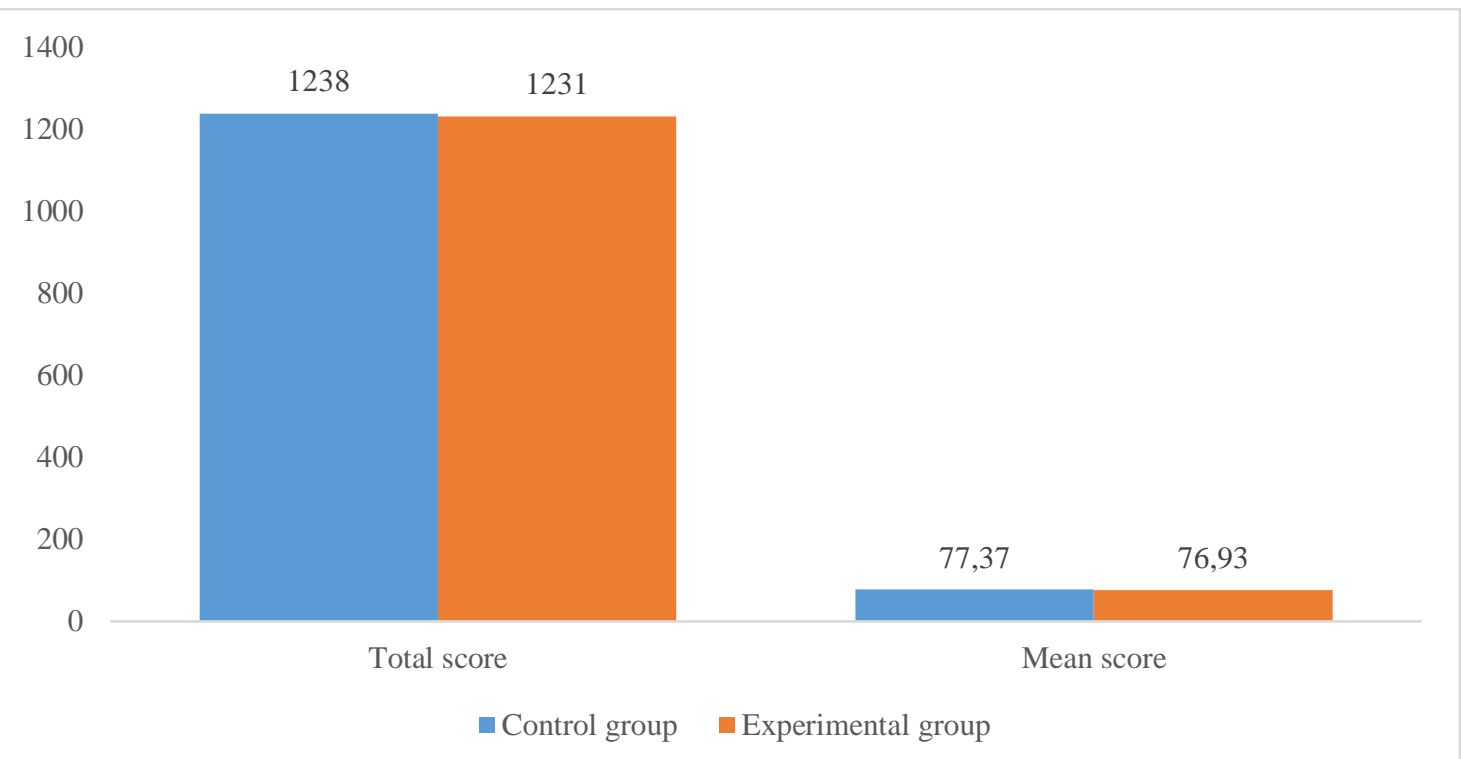

Diagram 1. Comparison of the pre-test results in the control and experimental groups. The results before and after the experiment in the control (the left-hand blue figure) and experimental (the right-hand orange figure) groups.

At the end of the pedagogical experiment, international students of both groups performed a test of reading comprehension (using the tasks: answer the questions, fill in the gaps, choose the correct answer), use of language (write a short letter in a foreign (Ukrainian) language on a proposed topic), listening (watch a short video of socio-cultural content and define if the

Table 5.

Post-testing results in the control group. statements are true or false and complete the sentences), speaking (present a spontaneous monologue on a proposed topic; during the conversation with the interlocutor prove own point of view on the proposed problem).

Post-testing results are presented in Table 5, Table 6, Diagram 2.

\begin{tabular}{lll}
\hline & Respondent's name & $\begin{array}{l}\text { Students' post-test score } \\
(0-100)\end{array}$ \\
\hline 1. & Student 1 & 70 \\
2. & Student 2 & 75 \\
3. & Student 3 & 72 \\
4. & Student 4 & 80 \\
5. & Student 5 & 65 \\
6. & Student 6 & 96 \\
7. & Student 7 & 83 \\
8. & Student 8 & 86 \\
9. & Student 9 & 94 \\
10. & Student 10 & 75 \\
11. & Student 11 & 79 \\
12. & Student 12 & 65 \\
13. & Student 13 & 75 \\
14. & Student 14 & 95 \\
15. & Student 15 & 83 \\
16. & Student 16 & 85 \\
Total Score & & 1278 \\
Mean score & & 79.88 \\
Mean score in percentage & & $79.88 \%$ \\
\hline
\end{tabular}


Table 6.

Post-testing results in the experimental group.

\begin{tabular}{lll}
\hline & Respondent's name & $\begin{array}{l}\text { Students' post-test score } \\
(0-100)\end{array}$ \\
\hline 1. & Student 1 & 84 \\
2. & Student 2 & 83 \\
3. & Student 3 & 90 \\
4. & Student 4 & 75 \\
5. & Student 5 & 68 \\
6. & Student 6 & 86 \\
7. & Student 7 & 76 \\
8. & Student 8 & 97 \\
9. & Student 9 & 78 \\
10. & Student 10 & 90 \\
11. & Student 11 & 87 \\
12. & Student 12 & 76 \\
13. & Student 13 & 97 \\
14. & Student 14 & 69 \\
15. & Student 15 & 76 \\
16. & Student 16 & 92 \\
Total Score & 1324 & \\
Mean score & & 82.75 \\
Mean score in percentage & & $82.75 \%$ \\
\hline
\end{tabular}

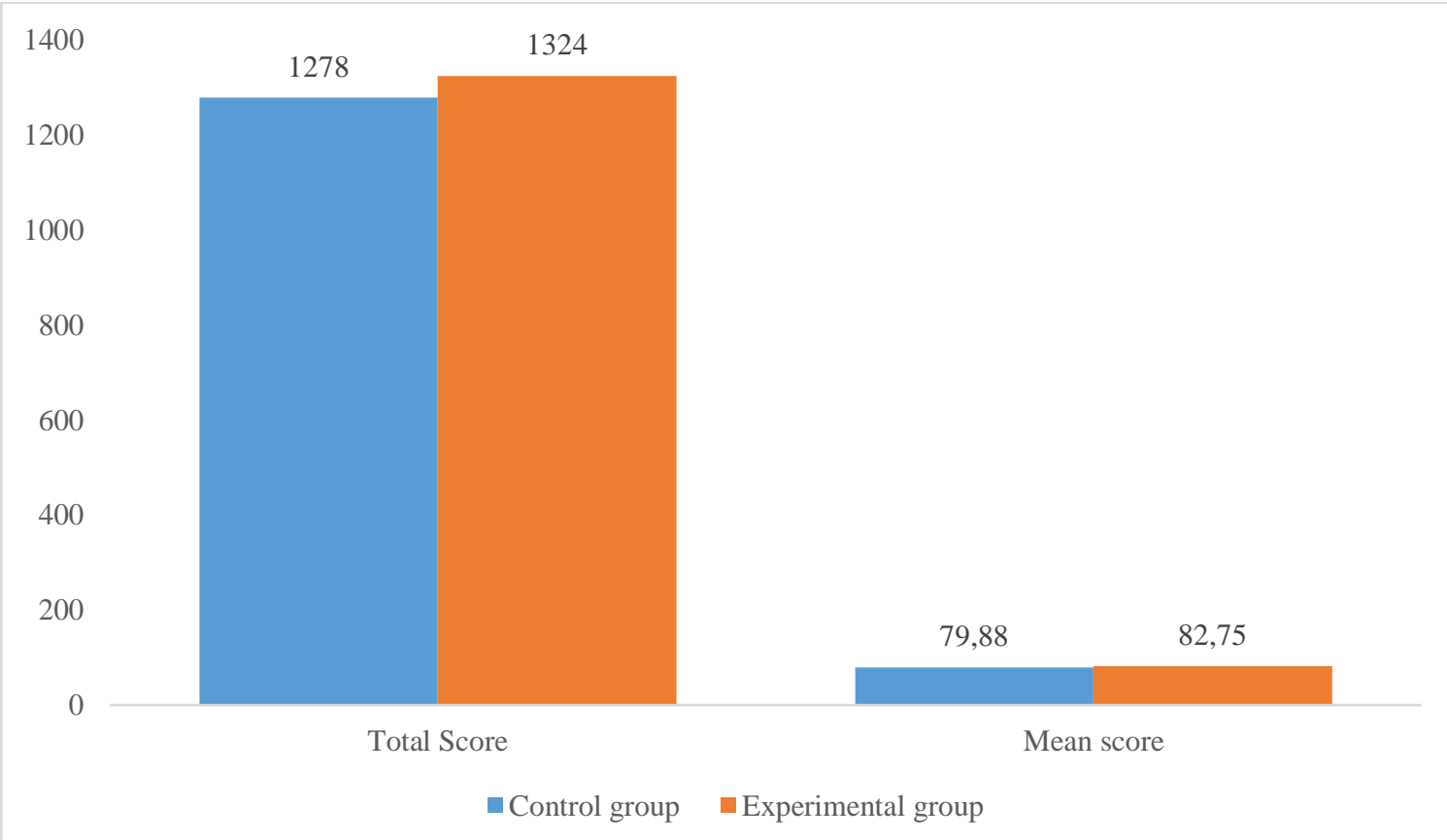

Diagram 2. Comparison of post-test results in control and experimental groups. The results before and after the experiment in the control (the left-hand blue figure) and experimental (the right-hand orange figure) groups.

After systematic work on project preparation in the experimental group during the period in the described conditions, international students showed positive dynamics in the development of reading, writing, listening, speaking skills. Mean score percentages' improvement from pre-test to the post-test in the control group is presented in Table 7, Diagram 3. 
Table 7.

The improvement score from the pre-test to the post-test in the control group.

\begin{tabular}{llll}
\hline Score & Pre-test & Post-test & $\begin{array}{l}\text { Students group } \\
\text { percentages' } \\
\text { improvement }\end{array}$ \\
\hline Total score & 1238 & 1278 & \\
$\begin{array}{l}\text { Students' mean score } \\
\begin{array}{l}\text { Mean score in } \\
\text { percentage }\end{array}\end{array}$ & 77.31 & 79.88 & \\
\hline
\end{tabular}

$80,50 \%$

$80,00 \%$

$79,88 \%$

$79,50 \%$

$79,00 \%$

$78,50 \%$

$78,00 \%$

$77,50 \%$

$77,31 \%$

$77,00 \%$

$76,50 \%$

$76,00 \%$

Percentage mean score

घre-test $\square$ post-test

Diagram 3. Comparison of the improvement percentage mean score from pre-test to the post-test in the control group.

Mean score percentages' improvement from pre-test to the post-test in the experimental group is presented in Table 8, Diagram 4.

Table 8.

The improvement score from pre-test to the post-test in the experimental group.

\begin{tabular}{llll}
\hline Score & Pre-test & Post-test & $\begin{array}{l}\text { Students group } \\
\text { percentages' } \\
\text { improvement }\end{array}$ \\
\hline Total score & 1231 & 1324 & \\
$\begin{array}{l}\text { Students' mean score } \\
\begin{array}{l}\text { Mean score in } \\
\text { percentage }\end{array}\end{array}$ & 76.93 & 82.75 & $5.82 \%$ \\
\hline
\end{tabular}




$$
\begin{aligned}
& 84,00 \% \\
& 83,00 \% \\
& 82,00 \% \\
& 81,00 \% \\
& 80,00 \% \\
& 79,00 \% \\
& 78,00 \% \\
& 77,00 \% \\
& 76,00 \% \\
& 75,00 \% \\
& 74,00 \%
\end{aligned}
$$

$82,75 \%$

$76,93 \%$

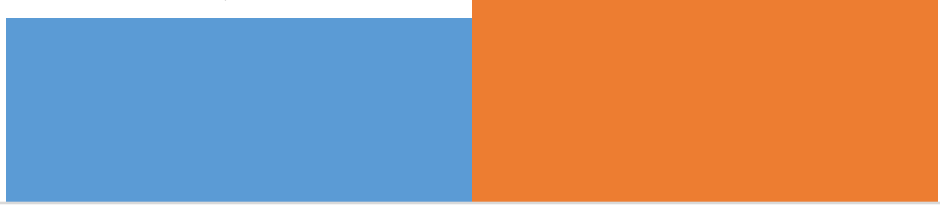

Percentage mean score

$\square$ pre-test $\quad$ post-test

Diagram 4. Comparison of the improvement percentage mean score from pre-test to the post-test in the experimental group.

As Diagram 5 shows at the end of the experiment in the experimental group compared with the control group, the test results are better.

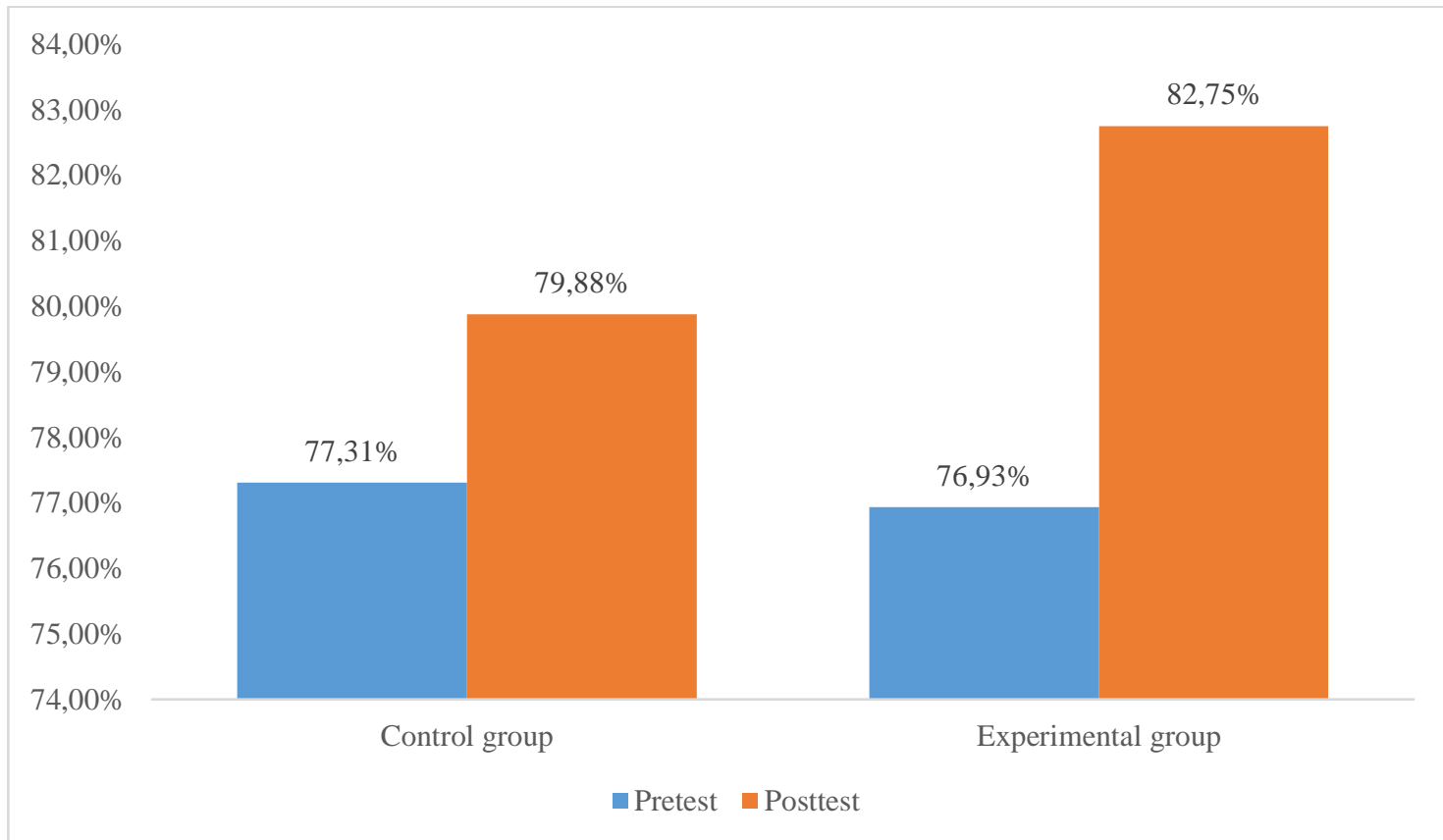

Diagram 5. Comparison of the improvement percentage mean score from pre-test to the post-test in the control and experimental groups.

Analysis and comparison of mean score improvement in percentage on the results of posttest in the control and experimental group are also worth attention. The appropriate data are represented in Table 9 and Diagram 6. 
Table 9.

The improvement of the mean score in percentage on the results of post-test in the control and experimental group.

\begin{tabular}{llll}
\hline Score & Control group & Experimental group & The improvement score \\
\hline $\begin{array}{l}\text { Students group } \\
\text { percentages' score }\end{array}$ & $79.88 \%$ & $82.75 \%$ & $2.87 \%$ \\
\hline
\end{tabular}

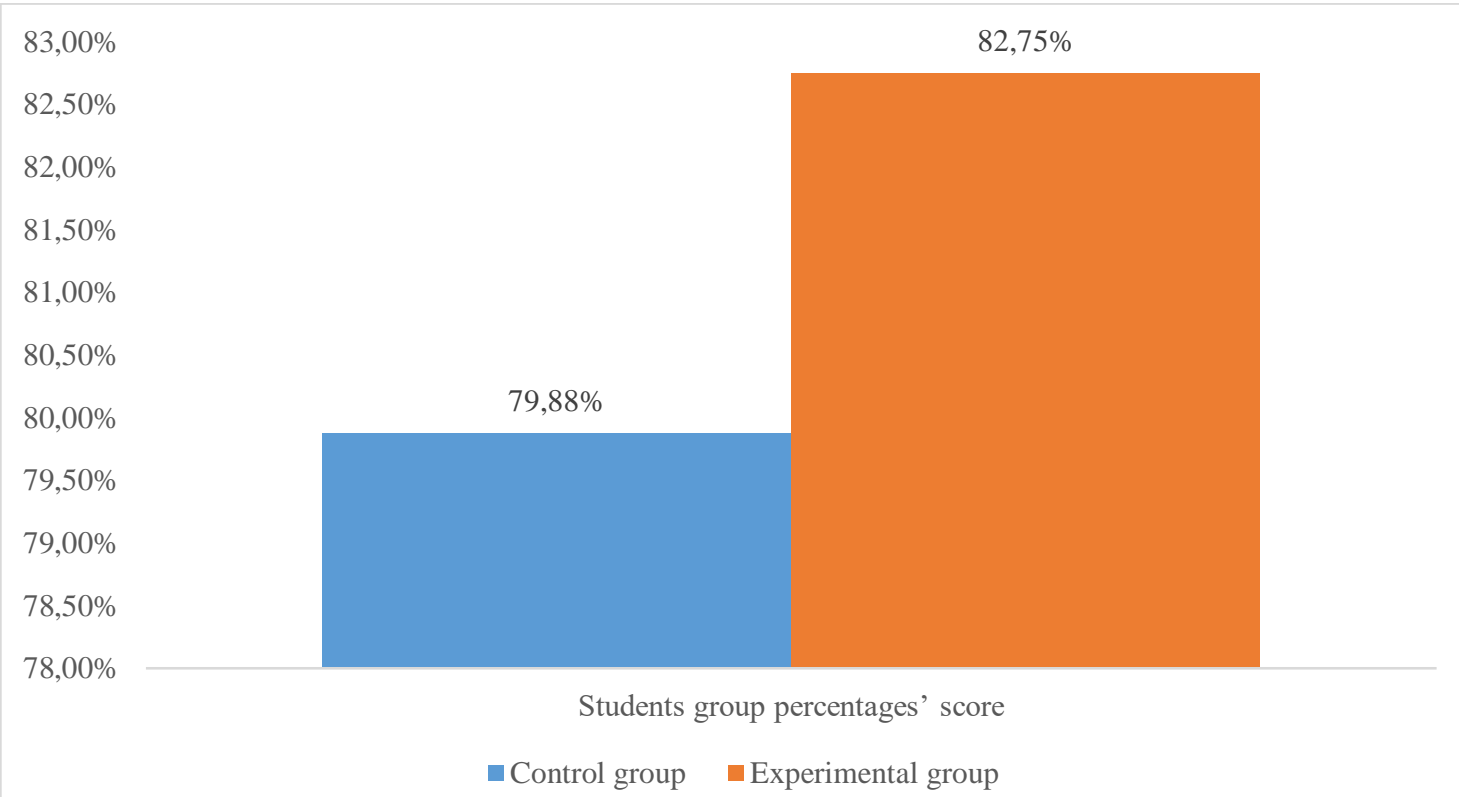

Diagram 6. The comparison of the improvement of students' mean score in percentage on the results of post-test after the experiment in the control (the left-hand figure) and experimental (the right-hand figure) groups.

The resulting data prove that international students in the experimental group improved their foreign (Ukrainian) language acquisition on average in 5.82 scores $(5.82 \%)$ compared with the results of the control group 2.57 scores $(2.57 \%)$. So, the results of tests in the experimental group revealed that the post-test scores and mean score were higher than their pretest scores after project activity implementation. Therefore, it can be concluded that international students' foreign language acquisition improved after the study.

The results of the study show that project activity during foreign language learning was effective for improving international students' language acquisition. The quantitative data analysis demonstrates progress in students' foreign language acquisition in the experimental group after the project activity implementation. Also, the participants of the experimental group enhanced their vocabulary and overcame possible individual awkwardness and fear that often arise when communicating in a foreign language. Such results in the control group can be explained by the fact that project activity involved all the components of foreign language competence (reading, writing, speaking, listening). In addition, the topics and stages of the implementation process for the project activity were drawn up especially for the needs of the first-year international students, taking into account the syllabus requirements (Lushchyk et al., 2020). And what is more, it confirms that methods of assistance and didactic support elaborated and suggested by the teachers were suitable for students' language level.

On the whole, international students' progress in a foreign language enables us to claim that the general improvement of the experimental group is significant. So, the statistical importance of the results obtained in the study is noteworthy too. The results of the experiment are specifically related to that circumstance that project activity fostered the international students to look for the necessary information and process it with pleasure, to be interested in a foreign language outside the classroom, to have positive attitude for foreign language learning; also, project 
activity boosted and encouraged real-life interaction. It should be emphasized the international students' high motivation determined by the fact they perform their project meeting their interests and views but not only the necessity to pass for a mark.

Project activity provided international students with opportunities to practice speaking, writing, listening skills through performing the presentation tasks as well as being involved in interaction with authentic environment. While preparing their projects students engaged in real communication and could apply topical knowledge and language skills. The stages of project work stimulated them to practice different skills (reading, writing, speaking, listening) during the learning and working process. In addition, they research the topic, search and process the important information from different sources in a foreign language. The presentation tasks and didactic underpinning were favorable and helpful for students' foreign language acquisition enhancement and promote them to use foreign language genuinely and deliberately.

\section{Discussion}

The experiment confirmed and extended the available knowledge of other scholars concerning the role of project activity in the process of foreign language acquisition.

The researchers' approach to understanding and defining the project activity mentioned above corresponds to internationally recognized studies. They relate to project-based learning both in general (Pecore, 2015; Thomas, 2000) and in the context of foreign language learning (Alan \& Stoller, 2005; Yufrizal, 2021). Projects are defined as "complex tasks, based on challenging questions or problems, that involve students in design, problem-solving, decision making, or investigative activities"(Thomas, 2000) as well as "an in-depth investigation of a real-world topic worthy of a student's attention and effort" (Yufrizal, 2021).

Analysis and generalization of characteristics, principles, and typology of projects allowed authors to focus on the aspects relevant for international students' foreign language learning. They are also close to the concepts introduced by Nguyen \& Nguyen (2019). The procedure of project activity involved several steps similar to stages of classroom planning, carrying out the project, reviewing and monitoring described by Richards \& Schmidt (2011) but in the study they were specially expanded and detailed for international students. The system for the implementation of the project activities developed by the researchers is in line with such key components of project-based learning as learner-centered environment, collaboration, curriculum content, authentic tasks, multiple presentation modes, etc. identified by Barrows (1988), Dewi (2016).

As it was demonstrated in our study, bearing in mind the above-mentioned points is beneficial for international students' foreign language acquisition. This research is alongside the experience of other scholars (Yufrizal, 2021; Brooks \& Wilson, 2015; García Mayo, 2019). Our outcomes confirm opinions from other research in the area, which show that project activities enable students to integrate language skills and content knowledge to complete the projects (Simpson, 2011; Syzenko \& Diachkova, 2020).

Also, this study demonstrates a good implementation plan. The results show that students not only received the necessary and sufficient preparation for the performance of projects but also improved their knowledge of a foreign language. In contrast, Poonpon (2011) indicates that inadequate preparation and lack of a clear plan to assist students can impede the successful completion of the project.

With regard to the improvement of students' language acquisition, the results of the study correspond to those of Srikrai (2008), Sirisrimangkorn (2021) who pointed out the beneficial effects of project-based learning on the students' language skills. In the current work the post-test results of the experimental group in reading, writing, speaking, and listening as well as vocabulary knowledge were enhanced because they were used to gain, analyze, and synthesize social-cultural information as international students working on their projects.

Integrating all four skills is not only an efficient use of class time but also each of the skills can reinforce each other through common vocabulary and language patterns. In order to create a balance of language skills, integration may be the best method of teaching. Integrating not only skills but also language and culture can have a mutually beneficial effect. (Oxford, 2001).

The selection of topics for project activities with a focus on socio-cultural content is also supported by modern researchers and considered as a means of contributing to the study of a 


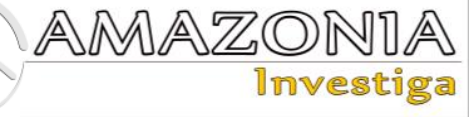

foreign language (Apple \& Kikuchi, 2007; Frances, 2018; Lushchyk et al., 2021; Maida, 2011; Tabaku \& Ecirli, 2014).

So, these findings and observation imply that properly organized project activities in which language skills, processing information from a variety of sources and authentic social-cultural topics and environment are merged and represent real-life tasks have a positive impact on foreign language acquisition by international students.

\section{Conclusion}

This study considered how project activity dealing with social-cultural content can be implemented in the context of foreign language learning by international students to foster them to use their language skills to wider knowledge and perform the task. It also evaluated how the social-cultural project combining in and outside the class activities improve international students' foreign language skills. The analysis of post-test results showed that the project implementation was appropriate for the course because students could apply and enhance their foreign language skills in real-life contexts during the project activity. A thorough plan and proper pedagogical support contributed to both the successful implementation of students' projects and the improvement of their foreign language acquisition.

The study gives some important educational findings. First, the theoretical issues in the area are numerous and diversified. They serve as a useful foundation for the practical application of the project activity in foreign language teaching and learning. Second, as the experiment demonstrates, the project activity has a positive impact on international students' ability to enhance their language skills during project implementation and stimulates their further foreign language acquisition. Performing the project is a complex, challenging, dynamic process that stipulates integration of relevant reading, writing, listening and speaking skills, knowledge to complete and introduce it. At the same time, the authors' support provided to students which covered the range of elaborated steps contributed significantly to the international students' headway in studying and foreign language acquisition. Thus, it makes sense to incorporate such social-cultural projects into foreign language learning by international students especially demonstrating the possibilities of language use outside the classroom in an authentic environment. It encourages them to use language skills and support their confidence in foreign language mastering

Prospective research may revolve around drawing on a variety of project activities in the process of foreign language learning using other criteria to test and evaluate their influence on students' foreign language acquisition.

\section{Bibliographic references}

Alan, B. \& Stoller, F. (2005). Maximizing the Benefits of Project Work in Foreign language Classrooms. English Teaching Forum, 43 (4), 10-21). doi: https://doi.org/10.12691/j1l-2-13.

Apple, M. \& Kikuchi, K. (2007). Practical PowerPoint group projects for the EFL classroom. The JALT CALL Journal, 3 (3), 110-122. DOI: https://doi.org/10.29140/jaltcall.v3n3.48

Barrows, H. S. (1988). The tutorial process. Springfield, IL: Southern Illinois University School of Medicine. https://www.ipleiria.pt/wpcontent/uploads/2016/05/H.-Barrows-TheTutorial-Process.pdf

Biletska, O., Kuchai, T., Kravtsova, T., Bidyuk, N., Tretko, V., \& Kuchai, O. (2021). The Use of the Activity Approach in Teaching Foreign Languages in Higher Education Institutions. Romanian Journal for Multidimensional Education [Revista Romaneasca Pentru Educatie Multidimensionala], 13(2), 243-267. https://doi.org/10.18662/rrem/13.2/420

Brooks, G. \& Wilson, J. (2015). Using oral presentations to improve students' English language skills. Kwansei Gakuin University Humanities Review, Vol 19, 199-212. https://core.ac.uk/download/pdf/143638488. pdf

Cuong, T. V. (2017). Organizing Project Based Teaching in the Training of Math Teachers in Vietnam. Revista Romanian Journal for Multidimensional Education [Revista Romaneasca Pentru Educatie Multidimensionala], 9(2), 9-35. DOI: http://dx.doi.org/10.18662/rrem/2017.0902.0 1

Dewi, H. (2016). Project based learning techniques to improve speaking skills. English Education Journal (EEJ), 7(3), 341-359, http://jurnal.unsyiah.ac.id/EEJ/article/view/4 588

Frances, S. (2018). Integrating 4 skills in a short project-based course. Journal of the Faculty of Letters. Kobe Shoin Women's University, 
7 ,

pp.

$1-12$

https://core.ac.uk/download/pdf/154916528. pdf

García Mayo, M. del. P. (2019). Learning in foreign language contexts. Language Teaching Research, 23(1), 5-8. https://doi.org/10.1177/1362168818822387

Gasparyan, L., Lashova, S., \& Pipchenko, E. (2018). Use of the project method in teaching Russian as a foreign language. [Ispol'zovanie proektnogo metoda $\mathrm{v}$ prepodavanii russkogo yazyka kak inostrannogo]. Russian Journal of Education and Psychology, 9(5), 50-61. https://cyberleninka.ru/article/n/ispolzovanie -proektnogo-metoda-v-prepodavaniirusskogo-yazyka-kak-inostrannogo/viewer

Haines, S. (1989). Projects for the EFL classroom. Thomas Nelson and Sons Ltd

Jarvis, P. \& Wilson, A., L. (2005). International dictionary of adult and continuing education. Taylor \& Francis e-Library, https://pls.fkip.unej.ac.id/wpcontent/uploads/sites/6/2017/01/INTERNAT IONAL-DICTIONARY-OF-ADULT-ANDCONTINUING-EDUCATION.pdf

Khatamova, Z., Ismailova, H., \& Akbarova, M. (2019). Project method in teaching English. European Journal of Research and Reflection in Educational Sciences, 7(12), 230-234. https://www.idpublications.org/wpcontent/uploads/2020/01/Full-PaperPROJECT-METHOD-IN-TEACHINGENGLISH.pdf

Konysheva, A. (2004). Modern methods of teaching English. [Sovremennye metody obucheniya anglijskomu yazyku]. Minsk: TetraSistems.

Koval, O. (2019). Project methods of teaching a foreign language to university students. [Proektna metodyka navchannia inozemnoi movy studentiv VNZ]. Pedagogy of formation of creative personality in higher and general education schools: coll. Science. to work, Vip. 6, vol. 2 (pp. 89-92) http://elar.tsatu.edu.ua/handle/123456789/83 42

Lushchyk, Y., Pikulytska, L., \& Tsyhanok, (2020). H. Core Curriculum for Foreigners' Language Training in Higher Agrarian Institutions: Correlation with Common European Recommendations. Romanian Journal for Multidimensional Education [Revista Romaneasca Pentru Educatie Multidimensionala], 12(1Sup1), 196-212. https://doi.org/10.18662/rrem/12.1 sup1/231

Lushchyk, Y., Pikulytska, L., \& Tsyhanok, H. (2021). Authentic Social-Cultural Reading in Foreign Language Learning and Teaching. Romanian Journal for Multidimensional
Education [Revista Romaneasca Pentru Educatie Multidimensionala], 13(4), 524542. https://doi.org/10.18662/rrem/13.4/496

Maida, C., (2011). Project-Based Learning: A Critical Pedagogy for the Twenty-First Century. Policy Futures in Education, 9(6), 759-768.

DOI: https://doi.org/10.2304/pfie.2011.9.6.759

Nguyen, L. \& Nguyen, L. (2019). Implementing Project Work in Teaching English at High School: The Case of Vietnamese Teachers' Challenges. International Journal of Foreign Language Teaching and Research, 7(26), 11-25.

https://www.researchgate.net/publication/34 4298660_Implementing_Project_Work_in_ Teaching_English_at_High_School_The_Ca se_of_Vietnamese_Teachers'_Challenges

Oxford, R. (2001). ERIC. Integrated skills in the ESL/EFL classroom. [Online]. Recovered from: https://files.eric.ed.gov/fulltext/ED456670.pdf

Pecore, J. L. (2015). From Kilpatrick's project method to project-based learning. International Handbook of Progressive Education, 155-171 https://ir.uwf.edu/islandora/object/uwf\%3A2 2741/datastream/PDF/view

Peters, M., A. (Ed.). (2017). Encyclopedia of educational theory and philosophy. Singapore: Springer https://doi.org/10.1007/978-981-287-5884

Polat, E. (1989). Theoretical foundations for the compilation and use of a system of teaching a foreign language for secondary schools. [Teoreticheskie osnovy sostavleniya i ispol'zovaniya sistemy sredstv obucheniya inostrannomu yazyku dlya srednej obshcheobrazovatel'noj shkoly]. (Abstract of Doctoral thesis), Academy of Pedagogical Sciences of the USSR, Research Institute of School Education and Teaching Techniques, Moscow.

Poonpon, K. (2011). Enhancing english skills through projectbased learning. The English Teacher, XL, 1-10 https://www.melta.org.my/journals/TET/do wnloads/tet40_01_01.pdf

Richards, J.C., \& Schmidt, R.W. (2011). Longman Dictionary of Language Teaching and Applied Linguistics (4th ed.). London: Routledge. https://doi.org/10.4324/9781315833835

Shcherbakova, I. A. (2011). Project method in teaching English: the relationship between study and practice. [Metod proektov pri obuchenii anglijskomu yazyku: vzaimosvyaz' ucheby i praktiki]. Kazan Pedagogical 


\section{AMAZONIA \\ Tnvestiga}

Journal,

(5-6),

33-40.

https://cyberleninka.ru/article/n/metodproektov-pri-obuchenii-angliyskomuyazyku-vzaimosvyaz-ucheby-ipraktiki/viewer

Simpson, J. (2011). Integrating project-based learning in an English language tourism classroom in a Thai university institution. (Doctoral Thesis) Australian Catholic University, Australia, https://doi.org/10.4226/66/5a961e4ec686b

Sirisrimangkorn, L. (2021) Improving EFL Undergraduate Learners' Speaking Skills Through Project-Based Learning Using Presentation. Advances in Language and Literary Studies, 12(3) p. DOI: http://dx.doi.org/10.7575/aiac.alls.v.12 n.3.p.65

Srikrai, P. (2008). Project-based learning in an EFL classroom. Journal of Humanities and Social Sciences, Khon Kean University, 25, 85-111.

https://www.researchgate.net/publication/28 1625201_Project-

Based_Learning_in_an_EFL_Classroom

Syzenko, A. \& Diachkova, Y. (2020). Building Cross-Cultural Competence in a Foreign Language through Technology-Enhance Project-Based Learning. Amazonia Investiga, 9(27), 411-418.

DOI:

http://dx.doi.org/10.34069/AI/2020.27.03.45

Tabaku, E., \& Ecirli, A. (2014) Project Work as a Means of Teaching Intercultural Communication Skills. Journal of Education and Practice, 5(9), 88-91 https://core.ac.uk/download/pdf/234635556. pdf

Thomas, J. W. (2000). A review of research on project-based learning. San Rafael, CA: Autodesk Foundation.

Tkhorikov, B., Semibratsky, M., Gerasimenko, O., \& Merezhko, A. (2018). Análisis de los enfoques metodológicos para la gestión de proyectos. Revista Científica Del Amazonas, 1(1), 29-37. Recuperado a partir de https://revistadelamazonas.info/index.php/a mazonas/article/view/4

Yermakov, I. (Ed.). (2003). Project method: traditions, perspectives, life results: practiceoriented collection. [Metod proektiv: tradytsii, perspektyvy, zhyttievi rezultaty: praktyko zoriientovanyi zbirnyk]. Kyiv: Departament

Yufrizal, H. (2021). The impact of project basedCLIL on students' english proficiency. Journal of Education and Learning (EduLearn), 15, 11-18. DOI: https://doi.org/10.11591/edulearn.v15i1.156 92 